\title{
ANALISIS PERBANDINGAN KEKUATAN TARIK ROLLER CHAIN (SUZUKI GENUINE PARTS) DAN (INDOPARTS) SATRIA FU 150
}

\author{
Christian Wely Wulur ${ }^{1}$, Andriyono ${ }^{2}$ \\ 1,2 Jurusan Teknik Mesin, Fakultas Teknik, Universitas Musamus \\ Email: ${ }^{1}$ christiantildjuir@gmail.com, ${ }^{2}$ andriyono@unmus.ac.id
}

\begin{abstract}
ABSTRAK
Uji Tarik adalah suatu metode yang digunakan untuk menguji kekuatan suatu bahan/material dengan cara memberikan beban gaya yang sesumbu. Hasil yang didapatkan dari pengujian tarik sangat penting untuk rekayasa teknik dan desain produk karena menghasilkan data kekuatan material. Penelitian ini bertujuan untuk mengetahui hasil uji tarik. Penelitian ini menggunakan metode penelitian pengujian tarik.

Dalam proses pengujian menggunakan sampel dari merk Indoparts dan Suzuki Genuine Parts.yang dimana setiap sampel terdiri dari 6 rangkaian rantai, 3 sample rangkaian rantai bermerk Indoparts dan 3 sample rangkaian rantai bermerk Suzuki Genuine Parts, yang seanjutnya dilakukan proses pengujian tarik.

Hasil peneitian yang telah dilakukan menunjukan bahwa nilai kekuatan tarik pada 6 sample rangkaian rantai yang masing-masing terdiri dari 3 sample untuk setiap merk yang diuji adalah, sample pertama Indoparts menghasilkan kekuatan tarik sebesar 14900,00 N, sample ke dua sebesar 15700,00 N , kemudian sample ke tiga $10700 \mathrm{~N}$. Setelah mendapat hasil pengujian tarik dari 3 sample Indoparts kemudian dilanjutkan kembali proses pengujian tarik terhadap 3 sample rantai merk Suzuki Genuine Parts. Dari hasil pengujian 3 sample Suzuki Genuine Parts pada sample pertama pengujian tarik menghasilkan nilai tarik sebesar $18700,00 \mathrm{~N}$, sample kedua sebesar 17000,00 N, dan sample ketiga menghasilkan nilai tarik sebesar 18500,0 N. Sesuai data tersebut dapat diketahui hasil uji tarik pada rantai Indopart dan Suzuki Genuine Parts, nilai rata-rata uji tarik rantai sebesar 18066,7 N adalah rantai dengan hasil uji tarik yang baik.
\end{abstract}

Kata kunci : Roller Chain, Indoparts, Suzuki Genuine Parts, Uji Tarik

\section{PENDAHULUAN}

Suatu logam mempunyai sifat-sifat tertentu yang dibedakan atas sifat fisik, mekanik, thermal, dan korosif. Salah satu yang penting dari sifat tersebut adalah sifat mekanik. Sifat mekanik terdiri dari keuletan, kekerasan, kekuatan, dan ketangguhan. Sifat mekanik merupakan salah satu acuan untuk melakukan proses selanjutnya terhadap suatu material, contohnya untuk dilakukan proses permesinan. Untuk mengetahui sifat mekanik pada suatu logam harus dilakukan pengujian tarik.
Uji Tarik adalah suatu metode yang digunakan untuk menguji kekuatan suatu bahan/material dengan cara memberikan beban gaya yang sesumbu. Hasil yang didapatkan dari pengujian tarik sangat penting untuk rekayasa teknik dan desain produk karena menghasilkan data kekuatan material. Pengujian tarik digunakan untuk mengukur ketahanan suatu material terhadap gaya statis yang diberikan secara lambat. Salah satu cara untuk mengetahui besaran sifat mekanik dari logam adalah dengan uji tarik. Sifat mekanik yang dapat diketahui adalah kekuatan dan elastisitas dari logam 
tersebut. Uji tarik banyak dilakukan untuk melengkapi informasi rancangan dasar kekuatan suatu bahan dan sebagai data pendukung bagi spesifikasi bahan. Nilai kekuatan dan elastisitas dari material uji dapat dilihat dari kurva uji tarik.

Rantai Motor adalah sesuatu bagian yang penting di sebuah sepeda motor. Karena sepeda motor merupakan kendaraan yang cocok digunakan untuk menjangkau berbagai daerah sampai termasuk daerah terpencil juga. Sebagai pengendara selayaknya harus mengetahui rantai apa yang baik dan cocok untuk kendaraan mereka sehari-hari. Selain sebagai alat transportasi yang terjangkau harganya dibandingkan dengan kendaraan roda empat, spare partnya pun terjangkau salah satunya adalah Roller Chain (rantai).

Untuk itu konsumen pun diharapkan mengetahui bagaimana cara memilih Roller Chain yang berkualitas dan bermutu buatan pabrikan original maupun non original karena masing-masing mempunyai ketahanan yang berbeda-beda. Merk atau brand rantai motor yang ada dipasaran banyak sekali. Masing- masing pabrikan bahkan memproduksinya dengan gear buatan mereka sendiri atau yang biasa disebut dengan gear set.

\section{TINJAUAN PUSTAKA}

\subsection{Uji Tarik}

Uji tarik adalah pemberian gaya atau tegangan tarik kepada material dengan maksud untuk mengetahui atau mendeteksi kekuatan dari suatu material. Tegangan tarik yang digunakan adalah tegangan perpanjangan sumbu benda uji. Uji tarik dilakuan dengan cara penarikan uji dengan gaya tarik secara terus menerus, sehingga bahan (perpajangannya) terus menerus meningkat dan teratur sampai putus, dengan tujuan menentukan nilai tarik.

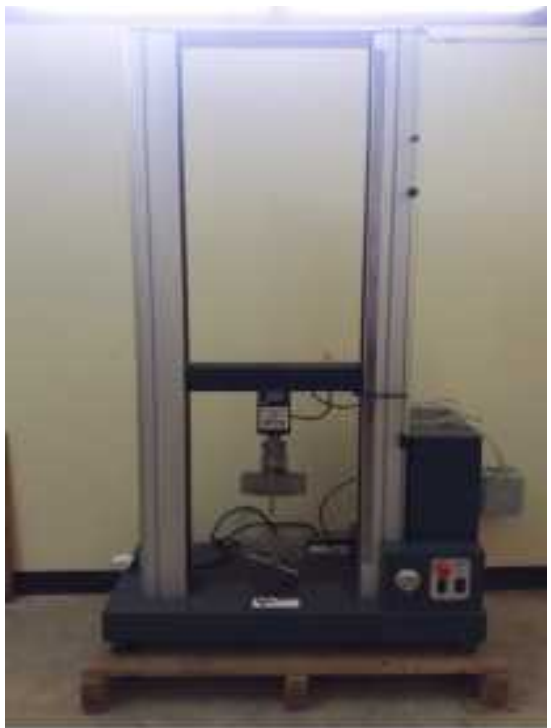

Gambar 1. Mesin Uji Tarik

\subsection{Tegangan - Regangan Teknis}

Sifat - sifat mekanik material yang dikuantifikasikan salah satunya dengan kuat tarik dapat diperoleh dengan pengujian tarik. Pada pengujian tarik uniaksial atau uji satu arah, benda uji diberi beban atau gaya tarik pada satu arah dan gaya yang diberikan bertambah besar secara kontinu. Pada saat bersamaan benda uji akan bertambah panjang dengan bertambah gaya yang diberikan. Berdasarkan hasil pengujian tarik yaitu berupa data gaya dan perpanjangan, maka dapat dianilisis untuk menentukan tegangan dan regangan secara teknis.

\subsection{Kekuatan Tarik}

Kekuatan Tarik atau kekuatan tarik maksimum (ultimate tensile strength) adalah nilai yang paling sering dituliskan sebagai hasil suatu uji tarik, tetapi pada kenyataannya nilai tersebut kurang bersifat mendasar dalam kaitannya dengan kekuatan material. Untuk logam ulet, kekuatan tariknya harus dikaitkan dengan beban maksimum, dimana logam dapat menahan beban sesumbu untuk keadaan yang sangat terbatas. Pada tegangan yang lebih komplek, kaitan nilai tersebut dengan kekuatan logam kecil sekali 
kegunaannya. Kecenderungan yang banyak ditemui adalah, mendasarkan rancangan statis logam ulet pada kekuatan luluhnya. Tetapi karena jauh lebih praktis menggunakan kekuatan tarik untuk menentukan kekuatan bahan, maka metode ini lebih banyak dipakai. Kekuatan tarik adalah besarnya beban maksimum dibagi dengan luas penampang lintang awal benda uji. Kekuatan yang biasanya ditentukan dari suatu hasil pengujian tarik adalah kuat luluh (Yield Strength) dan kuat tarik (Ultimate Tensile Strength). Kekuatan tarik atau kekuatan tarik maksimum (Ultimate Tensile Strength/UTS), adalah beban maksimum dibagi luas penampang lintang awal benda uji.

$$
S_{u}=\frac{P_{\text {maks }}}{A_{o}}
$$

$$
\begin{aligned}
\text { Dimana, } S_{u} & =\text { Kuat Tarik } \\
P_{\text {maks }} & =\text { Beban Maksimum } \\
A_{o} & =\text { Luas Penampang }
\end{aligned}
$$

Untuk logam-logam yang liat kekuatan tariknya harus dikaitkan dengan beban maksimum dimana logam dapat menahan sesumbu untuk keadaan yang sangat terbatas . tegangan tarik adalah nilai yang paling sering dituliskan sebagai hasil suatu uji tarik, tetapi pada kennyataannya nilai tersebut kurang bersifat mendasar dalam kaitannya dengan kekuatan bahan. Untuk logam-logam yang liat kekuatan tariknya harus dikaitkan dengan beban maksimum, dimana logam dapat menahan beban sesumbu untuk keadaan yang terbatas. Akan ditunjukan bahwa nilai tersebut kaitannya dengan kekuatan logam kecil sekali kegunaannya untuk tegangan yang lebih kompleks, yakni yang biasanya ditemui. Untuk berapa lama, telah menjadi kebiasaan mendasarkan kekuatan struktur pada kekuatan tarik, dikurangi dengan faktor keamanan yang sesuai.

Kecenderungan yang banyak ditemui adalah menggunakan pendekatan yang lebih rasional yakni mendasarkan rancangan statis logam yang liat pada kekuatan luluhnya. Akan tetapi, karena jauh lebih praktis menggunakan kekuatan tarik untuk menentukan kekuatan bahan, maka metode ini lebih banyak dikenal dan merupakan metode identifikasi bahan yang sangat berguna, mirip dengan kegunaan komposisi kimia untuk mengenali logam atau bahan. Selanjutnya, karena kekuatan tarik mudah ditentukan dan merupakan sifat yang mudah dihasilkan kembali (reproducible). Kekuatan tersebut berguna untuk keperluan spesifikasi dan control kualitas bahan. Korelasi empiris yang diperluas antara kekuatan tarik dan sifat-sifat bahan misalnya kekerasan dan kekuatan lelah, sering dipergunakan. Tegangan di mana deformasi plastis atau batas luluh teramati tergantung pada kepekaan pengukuran regangan. Sebagian besar bahan mengalami perubahan sifat dari elastik menjadi plastik yang berlangsung sedikit demi sedikit, dan titik dimana deformasi plastic mulai terjadi dan sukar ditentukan secara teliti. Telah digunakan berbagai kriteria permulaan batas luluh yang tergantung pada ketelitian pengukuran regangan dan data-data yang akan digunakan

1. Batas elastis sejati berdasarkan pada pengukuran regangan mikro pada skala 2 x 10-6 inci/inci. Batas elastik nilainya sangat rendah dan dikaitkan dengan gerakan beberapa ratus dislokasi.

2. Batas proporsional adalah tegangan tertinggi untuk daerah hubungan proporsional antara tegangan dan regangan. Harga ini diperoleh dengan cara 
mengamati peyimpangan dari bagian garis lurus kurva tegangan-regangan.

3. Batas elastis adalah tegangan terbesar yang masih dapat ditahan oleh bahan tanpa terjadi regangan sisa permanent yang terukur pada saat beban telah ditiadakan. Dengan bertambahnya ketelitian pengukuran regangan, nilai batas elastiknya menurun hingga suatu batas yang sama dengan batas elastis sejati yang diperoleh dengan cara pengukuran regangan mikro. Dengan ketelitian regangan yang sering digunakan (104inci/inci), batas elastis lebih besar dari pada batas proporsional.

\subsection{Kekuatan Luluh (Yield Strength)}

Salah satu kekuatan yang biasanya diketahui dari hasil pengujian tarik adalah kuat luluh (yield strength). Kekuatan luluh merupakan titik yang menunjukan perubahan deformasi elastis ke plastis. Besar tegangan luluh dituliskan seperti pada persamaan sebagai berikut.

$$
Y_{s}
$$

Keterangan:

Ys = Besarnya tegangan luluh $(\mathrm{Kg} / \mathrm{mm} 2)$

$\mathrm{Py}=$ Besarnya beban titik yield $(\mathrm{kg})$

$\mathrm{Ao}=$ Luas Penampang awal benda uji (mm2)

Tegangan dimana deformasi plastis atau batas luluh mulai teramati tergantung pada kepekaan pengukuran regangan. Sebagian besar bahan mengalami perubahan sifat dari elastik menjadi plastis yang berlangsung sedikit demi sedikit, dan titik dimana deformasi plastis mulai terjadi dan sukar ditentukan secara teliti.

Kekuatan luluh adalah tegangan yang dibutuhkan untuk menghasilkan sejumlah kecil deformasi plastis yang ditetapkan. Definisi yang sering digunakan untuk sifat ini adalah kekuatan luluh ditentukan oleh tegangan yang berkaitan dengan perpotongan antara kurva tegangan-regangan dengan garis yang sejajar dengan elastis ofset kurva oleh regangan tertentu. Di Amerika Serikat offset biasanya ditentukan sebagai regangan 0,2 atau 0,1 persen ( $e=0,002$ atau 0,001$)$.

Cara yang baik untuk mengamati kekuatan luluh offset adalah setelah benda uji diberi pembebanan hingga 0,2\% kekuatan luluh offset dan kemudian pada saat beban ditiadakan maka benda ujinya akan bertambah panjang 0,1 sampai dengan $0,2 \%$ lebih panjang daripada saat dalam keadaan diam. Tagangan offset di Britania Raya sering dinyatakan sebagian tegangan uji (proff stress), dimana harga offsetnya $0,1 \%$ atau $0,5 \%$. Kekuatan luluh yang diperoleh dengan metode offset biasanya dipergunakan untuk perancangan dan keperluan spesifikasi, karena metode tersebut terhindar dari kesukaran dalam pengukuran batas elastik atau batas proporsional.

\subsection{Pengukuran Keliatan}

Keuletan adalah kemampuan suatu bahan sewaktu menahan beban pada saat diberikan penetrasi dan akan kembali kebentuk semula. Secara umum pengukuran keuletan dilakukan untuk memenuhi kepentingan tiga buah hal yaitu:

1. Untuk menunjukan elongasi dimana suatu logam dapat berdeformasi tanpa terjadi patah dalam suatu proses suatu pembentukan logam, misalnya pengerolan dan ekstrusi.

2. Untuk memberi petunjuk secara umum kepada perancang mengenai kemampuan logam untuk mengalir secara plastis sebelum patah.

3. Sebagai petunjuk adanya perubahan permukaan kemurnian atau kondisi pengolahan. 
2. Bahan

\subsection{Modulus Elastisitas}

Keuletan adalah kemampuan suatu bahan sewaktu menahan beban pada saat diberikan penetrasi dan akan kembali kebentuk semula. Secara umum pengukuran keuletan dilakukan untuk memenuhi kepentingan tiga buah hal yaitu:

$$
\begin{aligned}
& M_{o} \\
& =\frac{S}{\varepsilon}
\end{aligned}
$$

Dimana, $\mathrm{s}=$ tegangan

$$
\text { = regangan }
$$
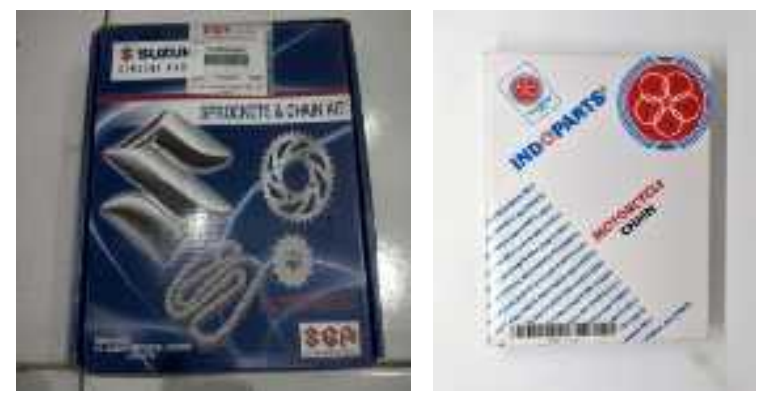

Gambar 2. Spesimen Uji Tarik

\section{METODE PENELITIAN}

3.1. Metode Pengumpulan Data

Metode yang digunakan dalam penelitian ini ialah sebagai berikut:

1. Studi pustaka.

2. Mempersiapkan alat dan bahan.

3. Melakukan pengujian material uji dan material pembanding.

\subsection{Alat dan bahan yang di gunakan}

1. Alat

Tabel 1.Alat yang di perlukan

\begin{tabular}{|c|l|c|}
\hline No & Alat & Jumlah \\
\hline 1 & Mesin Uji Tarik & 1 buah \\
\hline 2 & Jangka Sorong & 1 buah \\
\hline 3 & $\begin{array}{l}\text { Kaca mata } \\
\text { pelindung }\end{array}$ & 1 buah \\
\hline 4 & Sarung tangan & 1 pasang \\
\hline
\end{tabular}

Tabel 2. Bahan yang dibutuhkan

\begin{tabular}{|c|l|c|}
\hline No & Bahan & Jumlah \\
\hline 1 & Rantai SGP & 3 \\
\hline 2 & Rantai Indoparts & 3 \\
\hline
\end{tabular}

\subsection{Prosedur Pengujian}

Adapun prosedur pengujian yang di lakukan ialah sebagai berikut:

1. Mengukur benda uji ukuran standart.

2. Nyalakan mesin uji tarik dan lakukan pembebanan taik sampai benda uji putus.

3. Mencatat beban putus yang terdapat skala.

4. Melepaskan benda uji pada pegangan atas dan bawah kemudian satukan keduanya seperti semula.

5. Mencatat nilai uji tarik sampel.

\subsection{Pengambilan Data}

1. Melakukan pengujian terhadap spesimen.

2. Mengolah data dari hasil pengujian tarik..

3. Melakukan pembandingan hasil kedua specimen.

4. Kesimpulan.

3.6. Gambar Specimen Uji Tarik
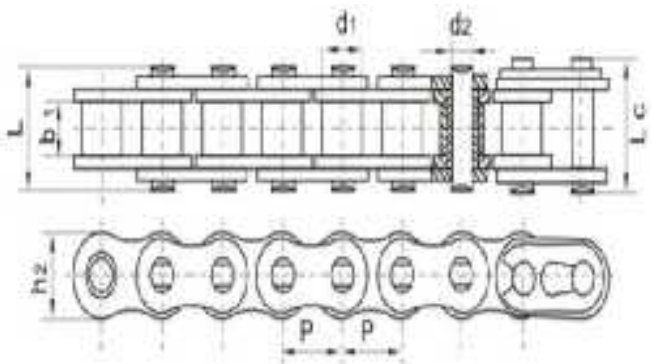

Gambar 3. Spesimen Uji Tarik

Keterangan : $\mathrm{b} 1=7.75 \mathrm{~mm}$

$$
\mathrm{d} 1=8.51 \mathrm{~mm}
$$




$$
\begin{aligned}
& \mathrm{d} 2=4.45 \mathrm{~mm} \\
& \mathrm{~h} 2=11.80 \mathrm{~mm} \\
& \mathrm{Lc}=18.10 \mathrm{~mm} \\
& \mathrm{P}=12.70 \mathrm{~mm}
\end{aligned}
$$

Benda yang diuji adalah tipe rantai yang digunakan untuk mentransmisikan tenaga mekanik ke roda. Spesimen berjumlah 6 buah yang terdiri dari 3 buah komponen spesimen dari rantai Suzuki Genuine Parts dan 3 Buah komponen spesimen dari rantai Indoparts. Pengujian dilakukan dengan menggunakan standart uji tarik spesimen ASTM E-8.

\subsection{Diagram Alur Penelitian}

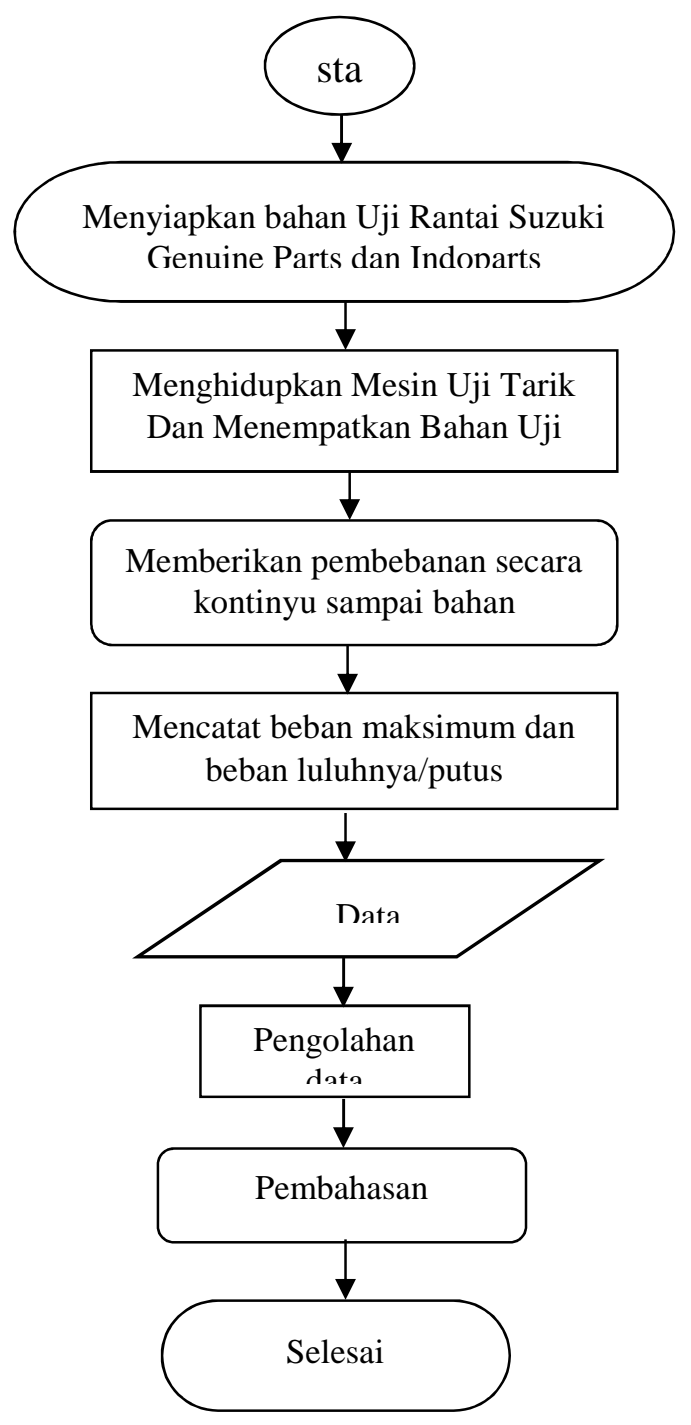

Gambar 4. Diagram Alur

\section{HASIL DAN PEMBAHASAN}

\subsection{Hasil pembuatan Spesimen}

Dalam pembutan spesimen ini digunakan bahan yang berbentuk rantai motor yang terdiri dari 2 Merk spesimen yang dimana specimen pertama adalah rantai dengan merk Suzuki Genuine Parts dan specimen keduanya adalah merk Indoparts. Kemudian masing-masing spesimen dipotong menjadi 3 rangkaian rantai spesimen Suzuki genuine parts, dan 3 rangkaian rantai spesimen merk Indoparts. Pengerjaan spesimen untuk uji tarik ini mengacu pada standar ASTM E-8.

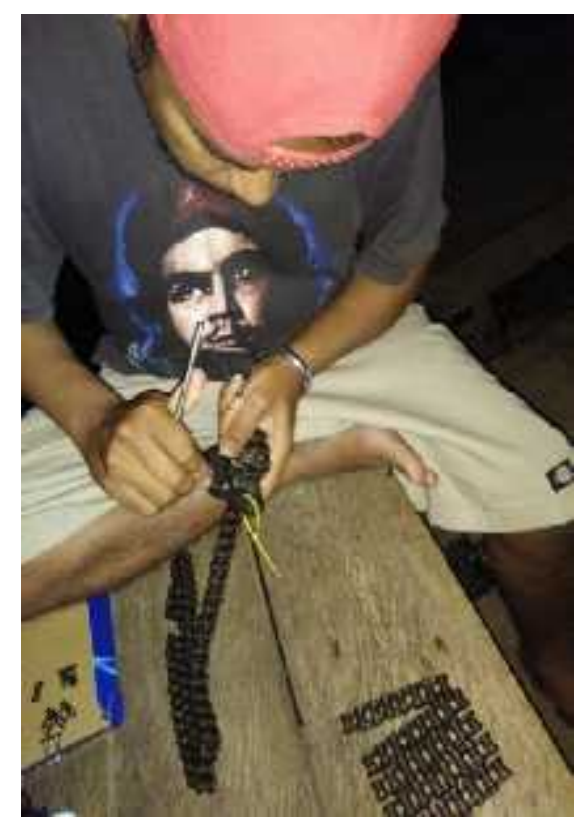

Gambar 5. Proses Pemotongan

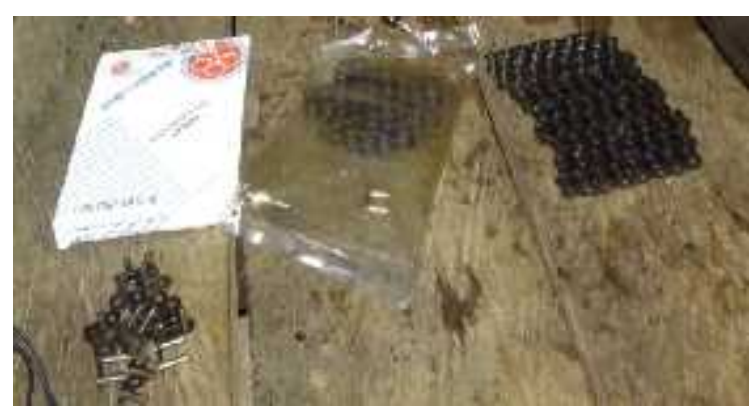

Gambar 6. Spesimen Rantai yang telah terpotong. 


\subsection{Hasil Pengujian Spesimen}

Pengujian tarik tidak dapat dipisahkan untuk mengetahui sifat-sifat dari suatu material/bahan. Kekuatan tarik adalah kapasitas bahan terhadap beban tarik. Hal ini dapat di ukur dengan beban/gaya maksimum berbanding terbalik dengan hasil luas penampang benda uji. Pengambilan data dengan melakukan uji tarik dapat mengetahui hasil dari presentase perpanjangan material dan presentase pengurangan/pengecilan penampang bada benda yang di uji, dan bisa diketahui sifat-sifat dari logam.

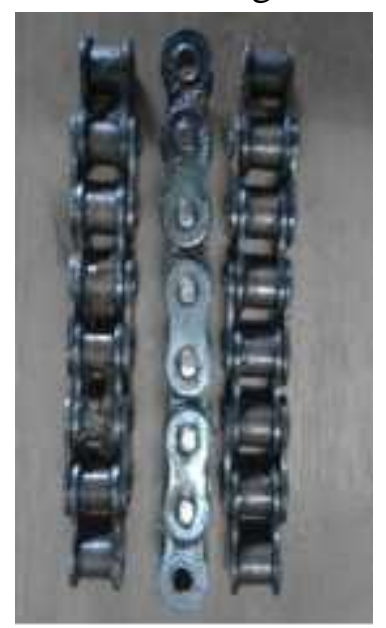

Gambar 7. Spesimen pada saat belum diuji tarik

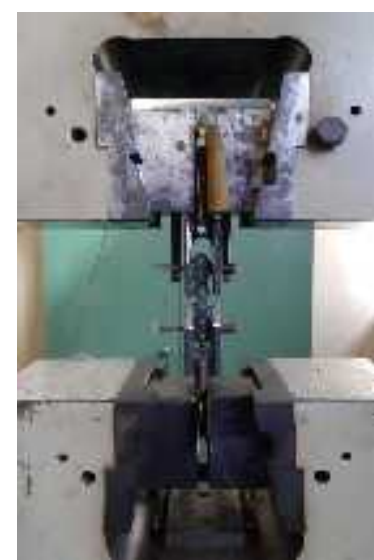

Gambar 8. Keadaan spesimen saat proses pengujian berlangsung

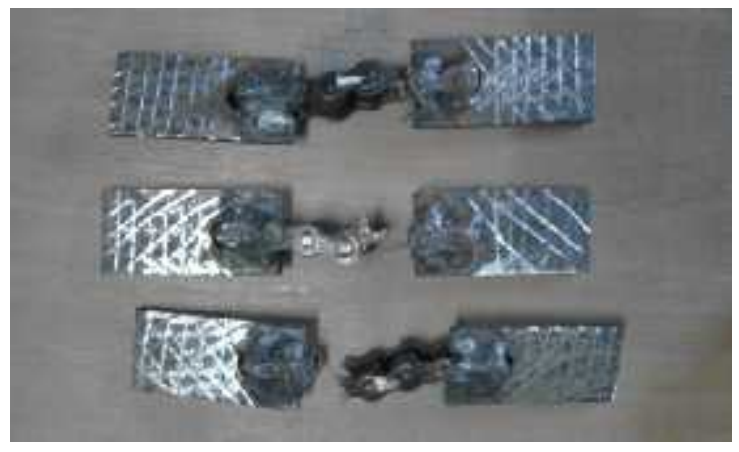

Gambar 9. Spesimen rantai setelah pengujian tarik

Berdasarkan hasil pengujian pada spesimen rantai Suzuki Genuine Parts dan Indoparts Maka diperoleh nilai dari hasil pengujian tersebut pada data yang akan disajikan pada tabel dibawah ini.

Tabel 3. Data pengujian tarik rantai Suzuki Genuine Parts

\begin{tabular}{|c|c|c|c|c|c|}
\hline \multirow[b]{2}{*}{ No } & \multirow{2}{*}{$\begin{array}{c}\text { Mveral } \\
\text { Stzaki Cenuiba Pats }\end{array}$} & \multicolumn{4}{|c|}{ Batrin Terk Miksomin } \\
\hline & & Stripal I & Sanpd 2 & Eampd 3 & Rata-me \\
\hline 1 & Tacopern: & $14900 \mathrm{C}$ & 15700,0 & 10700,0 & 13766,7 \\
\hline 2 & Strtiki Cemme Pats & 18700 & $1, \pi \times A, 0$ & 1850:.0 & 80667 \\
\hline
\end{tabular}

\subsection{PEMBAHASAN}

\subsubsection{Kekuatan Tarik Roller Chain}

Suzuki Genuine Parts

Dalam pembahasan berikut akan di jabarkan mengenai hasil kekuatan tarik pada sampel rantai Suzuki Genuine Parts. Yang dimana pengujian tarik dilakukan sebanyak 3 kali.

Tabel 4. Nilai hasil pengujian tarik Suzuki Genuine Parts

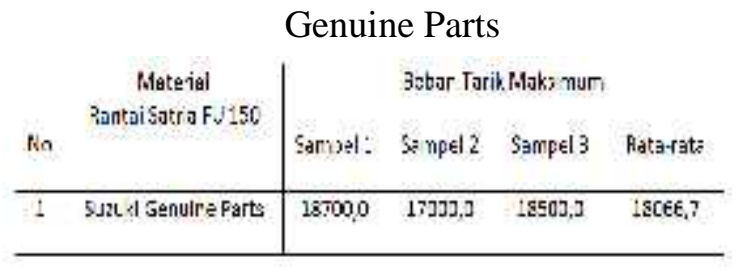




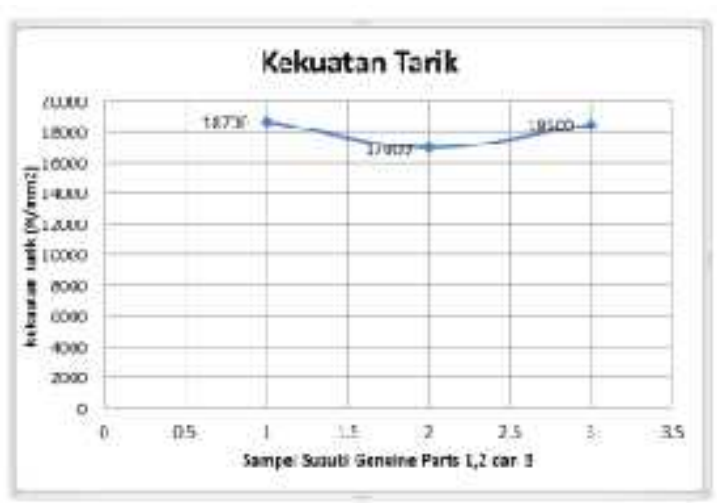

Gambar 10. Grafik Kekuatan Tarik Elektroda Rantai Suzuki Genuine Parts

Dari data hasil pengujian Tarik diatas bias dijelaskan bahwa pengujian Berdasarkan gambar 4.7, pada rantai Suzuki Genuine Parts menghasilkan nilai kekuatan tarik yang dilakukan sebanyak 3 kali pada specimen merk tersebut. Pada pengujian pertama didapatkan nilai kekuatan tarik sebesar $18700.00 \mathrm{~N}$, pengujian kedua didapatkan nilai kekuatan tarik sebesar $17000.00 \mathrm{~N}$ dan pengujian sampel rantai terakhir menghasilkan nilai kekuatan tarik sebesar 18500.0 N. Nilai kekuatan tarik material rantai Suzuki Genuine Parts yang dilakukan sebanyak 3 kali hasilnya tidak begitu terlampau jauh hasil nilai kekuatan tariknya.

Adanya perbedaan tersebut disebabkan karena modulus elastisitas adalah ukuran suatau bahan untuk mengetahui perbandingan antara tegangan dan reganggan, atau dapat dikatakan modulus elastisitas adalah ukuran untuk mengetahui kekakuan suatu material, jika nilai pada modulus elastisitas memiliki nilai yang tinggi, maka akan semakin rendah nilai rengangan atau yang terjadi dalam hal ini dapat dikatakan kaku, begitu pula sebaliknya jika nilai pada modulus elastisitas kecil, maka semakin besar nilai rengangannya.

\subsubsection{Kekuatan Tarik Roller Indoparts}

Dalam pembahasan berikut akan di jabarkan mengenai hasil kekuatan tarik pada sampel rantai Indoparts. Yang dimana pengujian tarik dilakukan sebanyak 3 kali.

Tabel 4.2.1 Nilai hasil pengujian tarik Indoparts

\begin{tabular}{|c|c|c|c|c|c|}
\hline \multirow[b]{2}{*}{ No } & \multirow{2}{*}{$\begin{array}{c}\text { Nasere } \\
\text { Ranta Sosta fu } 150\end{array}$} & \multicolumn{4}{|c|}{ Beban "arik Malienux } \\
\hline & & Sampal: & 3aาpe 2 & $\operatorname{Sin} x e^{3}$ & zats-rata \\
\hline 1 & Indeparts & 4302,0 & $15 \pi 0,0$ & $157 x, 0$ & $1306, j$ \\
\hline
\end{tabular}

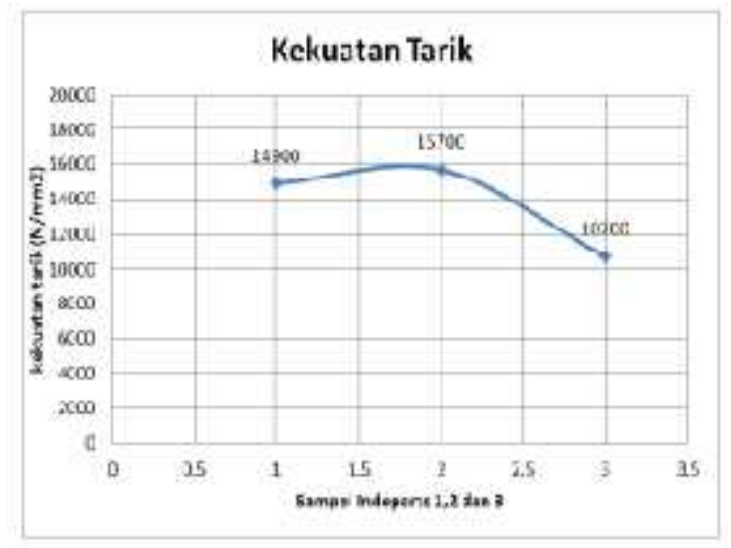

Gambar 11. Grafik Kekuatan Tarik Elektroda Rantai Indoparts

Dari data hasil pengujian Tarik diatas bias dijelaskan bahwa pengujian Berdasarkan gambar 4.8, pada rantai Indoparts menghasilkan nilai kekuatan tarik yang dilakukan sebanyak 3 kali pada specimen merk tersebut. Pada pengujian pertama didapatkan nilai kekuatan tarik sebesar $14900.00 \mathrm{~N}$, pengujian kedua didapatkan nilai kekuatan tarik sebesar $15700.00 \mathrm{~N}$ dan pengujian sampel rantai terakhir menghasilkan nilai kekuatan tarik sebesar 10570.0 N. Nilai kekuatan tarik material rantai Indoparts yang dilakukan sebanyak 3 kali hasilnya juga tidak begitu terlampau jauh hasil nilai kekuatan tariknya. Hasil nilai kekuatan tarik dari setiap satu specimen ke 
specimen lainnyapun mempunyai hasil yang berbeda.

\subsubsection{Perbandingan nilai hasil uji tarik specimen Roller Chain}

Dalam pembahasan berikut akan di jabarkan mengenai perbandingan Roller Chain merk Suzuki Genuine Parts dan Indoparts terhadap uji kekuatan tarik. Nilai hasil uji tarik diambil dari nilai rata-rata hasil pengujian tarik.

Tabel 4.4 Nilai hasil pengujian tarik.

\begin{tabular}{|cc|}
\hline Spesimes & Fasil Kekustan Tail \\
\hline Suzuki Sentine Parts & 18066,7 \\
\hline Irdopats & 13766,7 \\
\hline \hline
\end{tabular}

Berdasarkan tabel diatas hasil pengukuran nilai uji tarik dari specimen tersebut agar mudah dalam pembacaannnya maka di buat dalam bentuk grafik diagram batang (Histogram).

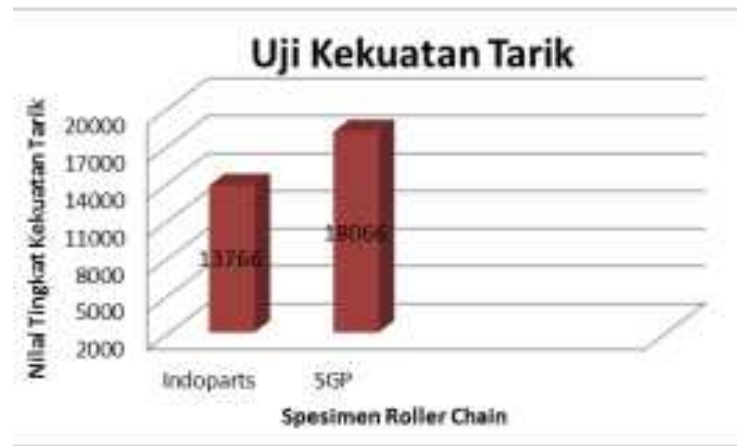

Gambar 11. Grafik Uji Tarik

Berdasarkan tabel diatas hasil pengukuran nilai uji tarik dari specimen tersebut agar mudah dalam pembacaannnya maka di buat dalam bentuk grafik diagram batang (Histogram).

\section{KESIMPULAN}

Dari hasil penelitian uji nilai tarik yang telah dilakukan terhadap masing masing specimen yaitu 3 spesimen Suzuki Genuine Parts dan Indoparts sebagai alat yang menyalurkan tenaga mesin ke roda penggerak maka dapat disimpulkan bahwa:

1. Kekuatan tarik rantai Suzuki Genuine Parts yang di rata-ratakan berada pada kekuatan tarik sebesar 18066,7 N.

2. Kekuatan tarik dari rantai Indoparts yang menghasilkan nilai kekuatan tarik yang dirata-ratakan berada pada $13766,7 \mathrm{~N}$.

\section{DAFTAR PUSTAKA}

[1] Akhir, T., \& Desain, B. S. (n.d.). $o$ PENDAHULUAN O DASAR TEORI $O$ METODOLOGI O ANALISA PERHITUNGAN o KESIMPULAN.

[2] Budiman, H. (2016). Analisis Pengujian Tarik 9Tensile Test) Pada Baja ST37 Dengan Alat Bantu Ukur Load Cell. JEnsitec, 03(01), 9-13.

[3] Iv, B. A. B., \& Strain, S. D. (n.d.). Bab iv sifat mekanik logam.

[4] Mekanikal, J., Renreng, I., Yamin, M., Ranggis, I. P., Mesin, D., Teknik,F., \& Hasanuddin, U. (2018). Analisis Kekuatan Tarik Rantai Pada Modular Conveyor. 9(1), 793-799.

[5] Salindeho, R. D., Soukota, J., \& Poeng, R. (2013). Pemodelan pengujian tarik untuk menganalisis sifat mekanik material. Jurnal J-Ensitec, 3(1), 1-11.

[6] Supit, G.R. 2012, Laporan Praktikum Pengujian Tarik Tembaga Poros Penampang Lingkaran, Laboratorium Teknik Mesin Unsrat. 